\title{
Fire and Nitrogen Effects on Purple Threeawn (Aristida purpurea) Abundance in Northern Mixed-Grass Prairie Old Fields
}

\author{
Dustin J. Strong, ${ }^{1}$ Lance T. Vermeire, ${ }^{2}$ and Amy C. Ganguli ${ }^{3}$ \\ Authors are ${ }^{1}$ Research Technician and ${ }^{2}$ Rangeland Ecologist, USDA-ARS Fort Keogh Livestock and Range Research Laboratory, Miles City, MT 59301, \\ USA; and ${ }^{3}$ Assistant Professor, Department of Animal and Range Sciences, New Mexico State University, Las Cruces, NM 88003, USA.
}

\begin{abstract}
Purple threeawn (Aristida purpurea Nutt. varieties) is a native grass capable of increasing on rangelands, forming near monocultures, and creating a stable state. Productive rangelands throughout the Great Plains and Intermountain West have experienced increases in purple threeawn abundance, reducing overall forage quality. Our objectives were to 1) reveal the effects of prescribed fire and nitrogen amendments on purple threeawn abundance and 2) assess nontarget plant response posttreatment. Season of fire (no fire, summer fire, fall fire) and nitrogen addition $\left(0 \mathrm{~kg} \mathrm{~N} \cdot \mathrm{ha}^{-1}, 46 \mathrm{~kg} \mathrm{~N} \cdot \mathrm{ha}{ }^{-1}\right.$, and $80 \mathrm{~kg}$ $\mathrm{N} \cdot \mathrm{ha}^{-1}$ ) were factorially arranged in a completely randomized design and applied to two similar sites in southeastern Montana. We evaluated fire and nitrogen effects on purple threeawn basal cover, relative composition, and current-year biomass one growing season postfire at two sites treated during different years. Spring weather following fire treatments was very different between years and subsequently impacted community response. Initial purple threeawn biomass at both sites was $1214 \pm 46$ $\mathrm{kg} \cdot \mathrm{ha}^{-1}$ SEc. When postfire growing conditions were wet, current-year biomass of purple threeawn was reduced $90 \%$ and $73 \%$ with summer and fall fire, respectively. Under dry postfire growing conditions, purple threeawn current-year biomass was reduced $73 \%$ and $58 \%$ with summer and fall fire, respectively. Nitrogen additions had no effect on purple threeawn currentyear biomass at either site. Current-year biomass of $\mathrm{C}_{3}$ perennial grass doubled with nitrogen additions and was not impacted by fire during a wet spring. Nitrogen additions and fire had no effect on $\mathrm{C}_{3}$ perennial grass current-year biomass following a dry spring. Prescribed fire appears to be a highly effective tool for reducing purple threeawn abundance on semiarid rangelands, with limited detrimental impacts to nontarget species.
\end{abstract}

Key Words: Aristida, grassland, nitrogen amendments, prescribed burning, restoration

\section{INTRODUCTION}

Aristida-dominated plant communities occur throughout the Great Basin and Great Plains. In most instances, purple threeawn (Aristida purpurea Nutt.) varieties are the primary species forming these near monocultures on semiarid rangelands. The catalyst for purple threeawn expansion appears to be intensive ecological disturbances such as plowing, prolonged overgrazing, exclusion of grazing, and fire suppression (Costello 1944; Evans and Tisdale 1972; Smeins et al. 1976; Milchunas et al. 1989). There is little information available on the total land area affected by purple threeawn dominance in North America. However, Aristida-dominated plant communities have been described in Australia and Africa (Paton and Rickert 1989; Kepe 2005) indicating Aristida dominance is not

Funding was provided by the Bureau of Land Management.

Mention of any trade name or proprietary product does not constitute a guarantee or warranty by the authors or USDA-ARS, nor does it imply the approval of these products to the exclusion of others.

The USDA-ARS Northern Plains Area is an equal opportunity/affirmative action employer, and all agency services are available without discrimination.

At the time of research, D. J. Strong and A. C. Ganguli were graduate student and Assistant Professor, respectively, School of Natural Resource Sciences, Range Program, North Dakota State University, Fargo, ND 58108, USA.

Correspondence: Dustin Strong, USDA-ARS Fort Keogh Livestock and Range Research Laboratory, 243 Fort Keogh Road, Miles City, MT 59301, USA. Email: Dustin. Strong@ars.usda.gov

Manuscript received 1 February 2013; manuscript accepted 12 June 2013.

(c) 2013 The Society for Range Management unique to semiarid rangelands in North America. Management strategies aimed at rehabilitating plant communities where purple threeawn has become dominant could be valuable to land managers on North America and other continents.

The seed morphology and root physiology of purple threeawn produce a long-lived, highly fecund plant with the ability to inhabit extreme environments (Judd 1974; Fowler 1984). Purple threeawn reproduces primarily by seed and has a sharp callus and three awns that allow for rapid burial and wind dispersal, respectively (Evans and Tisdale 1972; Fowler 1986). Following germination, purple threeawn initiates root growth relatively early and generally produces a robust root system (Evans and Tisdale 1972). This large root structure offers purple threeawn a significant advantage in semiarid grasslands, enabling it to take advantage of water and nutrients deeper in the soil (Burke et al. 1998).

Purple threeawn is a component of native plant communities on semiarid rangelands contributing $5-10 \%$ to the relative cover of a plant community (Hyder et al. 1975; Smeins et al. 1976). The ability of purple threeawn to readily colonize bare ground and inhabit hillsides increases soil stability by reducing wind and water erosion on these sensitive areas. However, the same characteristics that enable purple threeawn to occupy demanding environments enable purple threeawn to dominate more productive plant communities. A purple threeawn-dominated plant community presents a significant problem to livestock producers, because purple threeawn is generally avoided by livestock (Heitschmidt et al. 1990; Anderson and Briske 1995). Furthermore, when livestock utilize purple threeawn, its poor overall forage quality 
(Meyer and Brown 1985) may reduce livestock performance. Additionally, a purple threeawn-dominated plant community will remain in a stable state for $60+\mathrm{yr}$ (Tomanek 1955; Horn and Redente 1998). Management strategies that reduce purple threeawn abundance and stimulate the transition out of a purple threeawn-dominated state could improve overall palatability of these plant communities and diversify plant community composition.

Nitrogen amendments reduced purple threeawn cover and growing season biomass in eastern Colorado (Hyder and Bement 1972), but the mechanism associated with the reductions was not clear. Conversely, a similar experiment conducted $30 \mathrm{yr}$ later in the same area resulted in no change in purple threeawn cover or growing season biomass (Horn and Redente 1998). Additional research is needed to develop a more complete understanding of the relationship between purple threeawn and nitrogen.

Aristida species, in general, appear to be sensitive to fire (Trlica and Schuster 1969; Parmenter 2008), yet little information is available directly comparing purple threeawn response to different seasons of fire. Spring fire reduced perennial threeawn current-year biomass for two growing seasons in southern mixed-grass prairie (Steuter and Wright 1983). However, spring fire in the northern Great Plains may negatively impact the dominant $\mathrm{C}_{3}$ (cool-season) perennial grasses (White and Currie 1983). In contrast, the dominant $\mathrm{C}_{3}$ perennial grasses in the northern Great Plains appear to be resilient or respond positively to summer and fall burning (Engle and Bultsma 1984; Steuter 1987; Vermeire et al. 2011). Additionally, a greenhouse study indicated summer fire reduced purple threeawn through direct mortality and shifted dominance for surviving plants to favor competing species (Russell et al. 2013). Therefore, summer and fall fire may reduce purple threeawn abundance and have a minimal impact on the dominant $\mathrm{C}_{3}$ perennial grasses. The objectives of this study were to 1) evaluate the efficacy of nitrogen amendments and prescribed fire during different seasons as tools to reduce purple threeawn (target plant) abundance and 2) assess nontarget plant response following fire and nitrogen treatments.

\section{MATERIALS AND METHODS}

\section{Study Area}

We conducted this research in semiarid mixed-grass prairie near Terry, Montana, from July 2010 to July 2012. Average annual precipitation for the area is $295 \mathrm{~mm}$, with the majority occurring April through September. Average temperature is $6.6^{\circ} \mathrm{C}$, with extremes of $43.8^{\circ} \mathrm{C}$ in the summer and $-42.8^{\circ} \mathrm{C}$ in the winter. The frost-free growing season typically ranges from 105 to 135 d (Western Regional Climate Center 2012).

The research area is located within approximately 30000 ha of abandoned cropland seeded to crested wheatgrass from 1936 to 1942 (McWilliams and Van Cleave 1960). We selected two similar sites within $2.4 \mathrm{~km}$ of each other and treated them in different years to test the effects of fire and nitrogen on purple threeawn and account for environmental variability between years. Site 1 (lat $46^{\circ} 41^{\prime} \mathrm{N}$, long $\left.105^{\circ} 18^{\prime} \mathrm{W}\right)$ was treated in $2010-2011$ and Site 2 (lat $46^{\circ} 43^{\prime} \mathrm{N}$, long $105^{\circ} 18^{\prime} \mathrm{W}$ ) was treated in $2011-2012$. Both sites are sandy ecological sites characterized by flat, upland plains and the Degrand soil series (a fine-loamy over sandy or sandyskeletal, mixed, superactive, frigid Aridic Argiustolls; USDANRCS 2010a). Site 1 has been stocked at 0.12 animal unit months (AUMs) $\cdot \mathrm{ha}^{-1}$ from 1 April to 15 July and from 1 September to 14 November for a minimum of $40 \mathrm{yr}$, with the majority of utilization occurring in the spring. Site 2 has been stocked at 0.12 AUMs $\cdot \mathrm{ha}^{-1}$ from 1 May to 14 July and from 15 October to 22 November for a minimum of $40 \mathrm{yr}$, with the majority of utilization occurring in the spring. During the summer of 2009, we fenced each site to exclude cattle.

Vegetation at the study sites was dominated by the perennial $\mathrm{C}_{4}$ (warm-season) bunchgrass purple threeawn (Aristida purpurea Nutt.), and the perennial $\mathrm{C}_{3}$ bunchgrass crested wheatgrass (Agropyron cristatum [L.] Gaertn). Other $\mathrm{C}_{4}$ perennial grasses present included sand dropseed (Sporobolus cryptandrus [Torr.] A. Gray), blue grama (Bouteloua gracilis [Willd. ex Kunth] Lag. ex Griffiths), buffalograss (Bouteloua dactyloides [Nutt.] Engelm.), and tumblegrass (Schedonnardus paniculatus [Nutt.] Trel.). Other $\mathrm{C}_{3}$ perennial grasses included needle-and-thread (Hesperostipa comata [Trin. \& Rupr.] Barkworth), Sandberg bluegrass (Poa secunda J. Presl), and intermediate wheatgrass (Thinopyrum intermedium [Host] Barkworth \& D.R. Dewey). Annual grasses were sixweeks fescue (Vulpia octoflora [Walt.] Rydb.), field brome (Bromus arvensis L.), and cheatgrass (Bromus tectorum L.). The subshrub green sage (Artemisia campestris L.) was present in addition to hairy goldenaster (Chrysopsis villosa [Pursh.] Nutt.), the perennial legume silverleaf Indian breadroot (Pediomelum argophyllum [Pursh.] J. Grimes), and the biennial forb yellow salsify (Tragopogon dubius Scop.). Annual forbs included field cottonrose (Logfia arvensis [L.] Holub), woolly plantain (Plantago patagonica Jacq.), and rough false pennyroyal (Hedeoma hispida Pursh.). Plant nomenclature follows the USDA PLANTS database (USDA-NRCS 2010b).

\section{Experimental Design and Treatment Application}

We combined fire and nitrogen amendments in a fully factorial $3 \times 3$ arrangement by randomly assigning three fire treatments (no fire, summer fire, fall fire $)$ and three levels of nitrogen $(0 \mathrm{~kg}$ $\mathrm{N} \cdot \mathrm{ha}^{-1}, 46 \mathrm{~kg} \mathrm{~N} \cdot \mathrm{ha}^{-1}$, and $80 \mathrm{~kg} \mathrm{~N} \cdot \mathrm{ha}^{-1}$ ) with three replications to $2720 \times 20 \mathrm{~m}$ plots at each site. Fuel load at each site was approximately $2000 \mathrm{~kg} \cdot \mathrm{ha}^{-1}$ and all fires were set using the ringfire method (Wright and Bailey 1982). Summer fires were applied when purple threeawn seeds began dropping and fall fires were applied following the first killing frost. High fuel connectivity ensured complete fire coverage of all burned plots. We applied summer fire to Site 1 on 12 August 2010 with ambient temperatures $28-32^{\circ} \mathrm{C}$, winds $8-11 \mathrm{~km} \cdot \mathrm{h}^{-1}$, and relative humidity $36-42 \%$. Fall fires were applied at Site 1 on 18 October 2010 with ambient temperatures $17-18^{\circ} \mathrm{C}$, winds $8-13 \mathrm{~km} \cdot \mathrm{h}^{-1}$, and relative humidity $35-37 \%$. Nitrogen amendments were applied during spring and planned to precede predicted precipitation. The nitrogen amendments were selected to correspond with the lower rates of nitrogen applied by Hyder and Bement (1972) that were effective in reducing purple threeawn in Colorado. We broadcasted nitrogen amendments (granular urea) on individual plots at Site 1 on 26 April 2011 , with ambient temperatures of $10-13^{\circ} \mathrm{C}$. Precipitation fell as rain the evening of 26 April. We applied summer fire at Site 2 on 7 September 2011 with ambient 


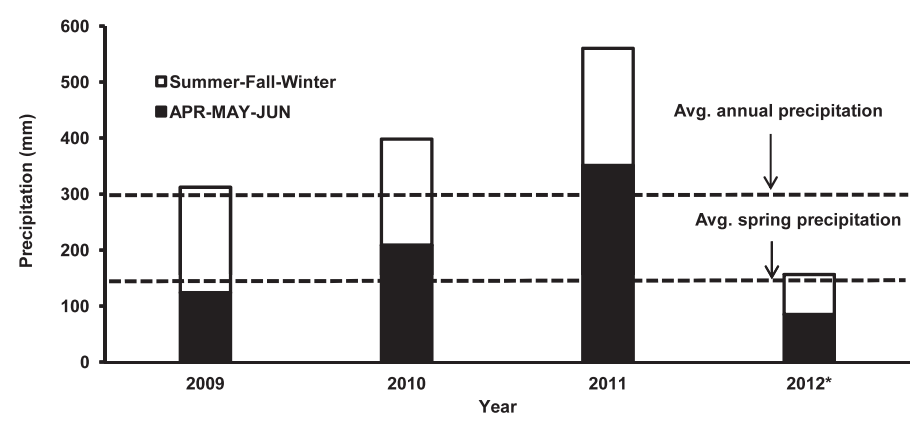

Figure 1. Annual, spring, and 75-yr average precipitation for Terry, Montana from 2008 to 2012. ${ }^{\star} 2012$ total is through August.

temperatures $29-31^{\circ} \mathrm{C}$, winds $5-13 \mathrm{~km} \cdot \mathrm{h}^{-1}$, relative humidity $15-20 \%$. Fall fires were applied at Site 2 on 31 October 2011 with ambient temperatures $16-20^{\circ} \mathrm{C}$, winds $13-30 \mathrm{~km} \cdot \mathrm{h}^{-1}$, and relative humidity $28-34 \%$. We applied nitrogen amendments to individual plots at Site 2 on 5 April 2012 with ambient temperature $10-13^{\circ} \mathrm{C}$. The first postapplication precipitation fell as rain on 26 April 2012.

\section{Vegetation Measurements}

To assess vegetation response to our treatments we measured standing crop, current-year biomass, basal cover, bare ground, litter, and relative composition. All vegetation sampling occurred at peak biomass (mid-July). We read four 5-m transects at $20-\mathrm{cm}$ intervals using the line point-intercept method to quantify basal cover, bare ground, and litter at the surface and relative composition based on canopy and basal hits. Transect starting points and directions were random with the restriction they could not overlap. Standing crops (the sum of current-year biomass and residual biomass from previous year's growth) of purple threeawn and the functional groups$\mathrm{C}_{3}$ perennial grass, other $\mathrm{C}_{4}$ perennial grass, annual grass, and forbs-were estimated by clipping each to ground level in five randomly placed $0.25-\mathrm{m}^{2}$ quadrats within each plot. Standing crops were estimated before fire treatment and during the growing season after treatment. Current-year biomass was estimated in the laboratory for purple threeawn and functional group by sorting current-year growth from total standing crop samples. Harvested vegetation was dried at $60^{\circ} \mathrm{C}$ for $48 \mathrm{~h}$ and weighed to the nearest $0.01 \mathrm{~g}$.

\section{Statistical Analysis}

Site and year had the potential to be confounded because sites were treated during different years. We initially used analysis of covariance in SAS (Littell et al. 2006) to determine whether pretreatment standing crops were significant covariates and tests indicated they were not. We then used analysis of variance (ANOVA) to compare Site 1 data to Site 2 data that were collected concurrently from nonburned, nonfertilized plots to determine whether standing crops varied by site. Analyses indicated standing crop components were similar between sites, so we concluded posttreatment differences detected between sites were attributable to year. Ultimately, we analyzed data from Site 1 and Site 2 using ANOVA to quantify plant community response one growing season after fire. Our models included treatment year, fire, nitrogen, and all interactions as fixed effects. We used basal cover, bare ground, litter, relative composition, standing crop, current-year biomass, and currentyear biomass by functional group as response variables and our experimental unit was plot. Mean separations were determined with $t$ tests of pairwise comparisons using the PDIFF option with the LSMEANS statement following significant $\mathrm{F}$ tests on main effects or interactions. Statistical significance was declared at $P<0.05$ for all tests.

\section{RESULTS}

\section{Weather}

Growing conditions at Site 1 (2011) and Site 2 (2012) were very different during the year following fire (Fig. 1). Spring 2011 (April-June) provided a record amount of precipitation (251\% of average) and spring 2012 was $25 \%$ drier than average. Regionally, 2012 was the second driest spring on record (Western Regional Climate Center 2012).

\section{Standing Crop and Current-Year Biomass}

Summer and fall fires yielded similar standing crops (1549 $\mathrm{kg} \cdot \mathrm{ha}^{-1}$ vs. $\left.1740 \pm 71 \mathrm{~kg} \cdot \mathrm{ha}^{-1} ; P<0.01\right)$ and both reduced standing crop relative to nonburned sites $\left(2873 \pm 71 \mathrm{~kg} \cdot \mathrm{ha}^{-1}\right)$. Spring weather and nitrogen interacted in their effects on standing crop $(P<0.01$; Fig. $2 \mathrm{~A})$, with nitrogen causing the greatest increase in standing crop when applied during a wet spring.

Nitrogen amendments increased current-year biomass when applied during a wet or dry spring, with no difference between $46 \mathrm{~kg} \mathrm{~N} \cdot \mathrm{ha}^{-1}$ and $80 \mathrm{~kg} \mathrm{~N} \cdot \mathrm{ha}^{-1}$ within spring weather $(P<0.01$; Fig. 2B). Summer and fall fire reduced current-year biomass following a wet spring, with summer fire having a greater effect than fall fire $(P<0.01$; Fig. 3A). Fire had no effect on current-year biomass following a dry spring.

Purple threeawn current-year biomass was reduced by fire $(P<0.01$; Fig. 3B). Summer fire had a greater effect on purple threeawn than fall fire following a wet spring, but summer and fall fire effects were similar following a dry spring. Summer fire yielded a $90 \%$ reduction in purple threeawn current-year biomass when followed by a wet spring and a $73 \%$ reduction when followed by a dry spring. Fall fire reduced purple threeawn current-year biomass $65 \%$ and $58 \%$ when followed by a wet and dry spring, respectively. Nitrogen amendments had no effect on purple threeawn current-year biomass $\left(345 \pm 30 \mathrm{~kg} \cdot \mathrm{ha}^{-1} ; P>0.5\right)$. Current-year biomass of $\mathrm{C}_{3}$ perennial grass was similar between burned and nonburned plots regardless of spring weather $\left(1262 \pm 75 \mathrm{~kg} \cdot \mathrm{ha}^{-1}\right.$; $P>0.09)$. Nitrogen amendments more than doubled currentyear biomass of $\mathrm{C}_{3}$ perennial grass during a wet spring, but had no effect during a dry spring $(P<0.01$; Fig. $2 \mathrm{C})$.

Current-year biomass of $\mathrm{C}_{4}$ perennial grass was similar following a wet or dry spring $\left(42 \pm 9 \mathrm{~kg} \cdot \mathrm{ha}^{-1} ; P>0.19\right)$. Current-year biomass of $\mathrm{C}_{4}$ perennial grass was similar in burned and nonburned plots $\left(41 \pm 11 \mathrm{~kg} \cdot \mathrm{ha}^{-1} ; P>0.49\right)$ but increased in plots receiving $46 \mathrm{~kg} \mathrm{~N} \cdot \mathrm{ha}^{-1}\left(59 \mathrm{~kg} \cdot \mathrm{ha}^{-1}\right.$ vs. $\left.17 \pm 11 \mathrm{~kg} \cdot \mathrm{ha}^{-1} ; P<0.03\right)$ and $80 \mathrm{~kg} \mathrm{~N} \cdot \mathrm{ha}^{-1}\left(48 \mathrm{~kg} \cdot \mathrm{ha}^{-1}\right.$ vs. $\left.17 \pm 11 \mathrm{~kg} \cdot \mathrm{ha}^{-1}\right)$. Forb current-year biomass more than doubled in nonburned plots receiving $46 \mathrm{~kg} \mathrm{~N} \cdot \mathrm{ha}^{-1}$ 


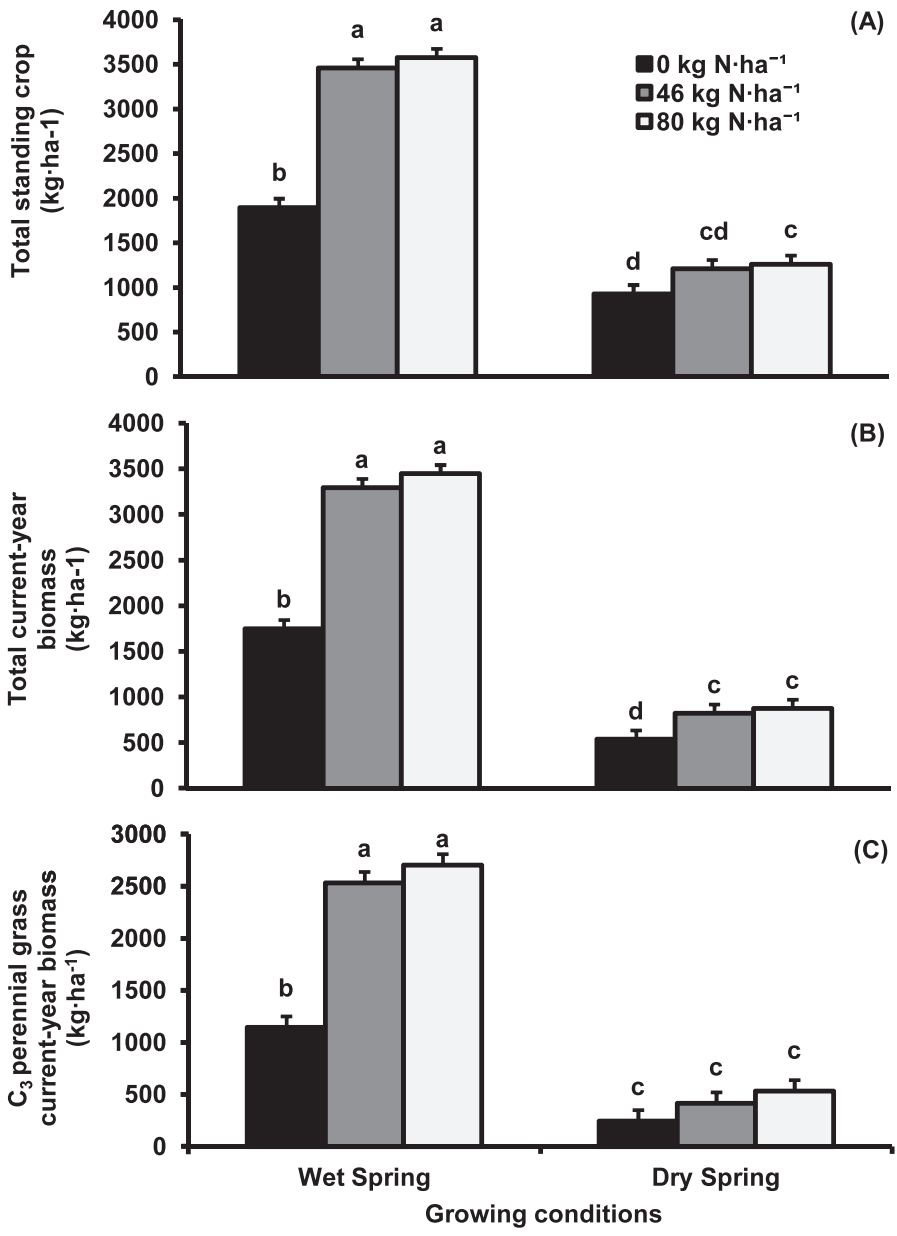

Figure 2. Nitrogen effects on A, total standing crop; B, total current-year biomass; and $\mathrm{C}, \mathrm{C}_{3}$ perennial grass current-year biomass (+SEc) under wet and dry spring growing conditions. Means marked with the same letter within a panel are similar $(P>0.05)$.

$\left(516 \pm 55 \mathrm{~kg} \cdot \mathrm{ha}^{-1} ; \mathrm{P}<0.03\right)$ and $80 \mathrm{~kg} \mathrm{~N} \cdot \mathrm{ha}^{-1}(411 \pm 55$ $\left.\mathrm{kg} \cdot \mathrm{ha}^{-1}\right)$ compared to the control $\left(196 \pm 55 \mathrm{~kg} \cdot \mathrm{ha}^{-1}\right)$ following a wet spring. All other treatment combinations yielded values similar to the control $\left(196 \pm 55 \mathrm{~kg} \cdot \mathrm{ha}^{-1}\right)$. Following a dry spring, forb current-year biomass was similar in all plots $\left(106 \pm 55 \mathrm{~kg} \cdot \mathrm{ha}^{-1}\right)$. Annual grass current-year biomass was similar across nitrogen treatments regardless of spring weather $\left(9 \pm 3 \mathrm{~kg} \cdot \mathrm{ha}^{-1} ; P>0.29\right)$. Following a wet spring, summer and fall fire reduced annual grass current-year biomass $56 \%$ (16 $\mathrm{kg} \cdot \mathrm{ha}^{-1}$ vs. $\left.36 \pm 4 \mathrm{~kg} \cdot \mathrm{ha}^{-1}\right)$ and $94 \%\left(2 \mathrm{~kg} \cdot \mathrm{ha}^{-1}\right.$ vs $36 \pm 4$ $\left.\mathrm{kg} \cdot \mathrm{ha}^{-1} ; P<0.01\right)$, respectively. Following a dry spring, annual grasses were virtually absent and current-year biomass was similar across treatments $\left(0 \pm 4 \mathrm{~kg} \cdot \mathrm{ha}^{-1}\right)$.

\section{Ground Cover}

Purple threeawn basal cover was greater in all plots following a dry spring than a wet spring $(P<0.01$; Table 1$)$. Regardless of spring weather, summer and fall fire reduced purple threeawn basal cover $94 \%$ and $85 \%$, respectively. Purple threeawn basal cover was similar for $0 \mathrm{~kg} \mathrm{~N} \cdot \mathrm{ha}^{-1}, 46 \mathrm{~kg} \mathrm{~N} \cdot \mathrm{ha}^{-1}$, and $80 \mathrm{~kg}$ $\mathrm{N} \cdot \mathrm{ha}^{-1}(P>0.69)$. Needle-and-thread basal cover was less during wet spring weather $(P<0.01)$ and reduced by fire $(P<0.01)$. Nitrogen amendments had no effect on needle-and-
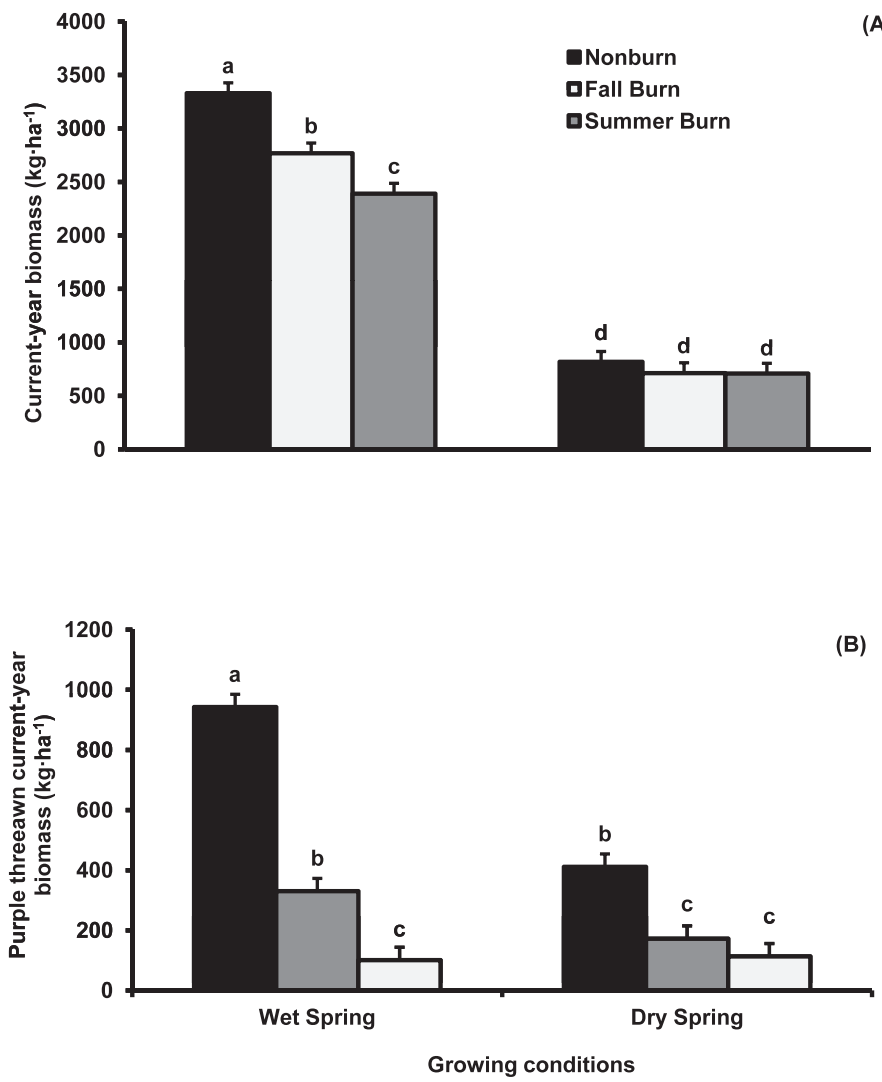

Figure 3. Fire effects on $A$, current-year biomass $(+S E c)$ and $B$, purple threeawn current-year biomass $(+\mathrm{SEc})$ one growing season postfire under wet and dry spring growing conditions. Means marked with the same letter within a panel are similar $(P>0.05)$.

thread basal cover $(P>0.49)$. Bare ground was greater following a dry spring than a wet spring $(P<0.01)$. Summer fire resulted in the most bare ground, followed by fall fire. Plots receiving $46 \mathrm{~kg} \mathrm{~N} \cdot \mathrm{ha}^{-1}$ had less bare ground than plots receiving $0 \mathrm{~kg} \mathrm{~N} \cdot \mathrm{ha}^{-1}$, but bare ground in plots treated with 80 $\mathrm{kg} \mathrm{N} \cdot \mathrm{ha}^{-1}$ was intermediate and similar to plots receiving 46 $\mathrm{kg} \mathrm{N} \cdot \mathrm{ha}^{-1}$ and $0 \mathrm{~kg} \mathrm{~N} \cdot \mathrm{ha}^{-1}(P<0.03)$.

Fire and spring weather interacted in their effects on crested wheatgrass basal cover $(P<0.01$; Fig. 4). Crested wheatgrass basal cover tripled with summer fire and more than doubled with fall fire following a wet spring. Following a dry spring, crested wheatgrass basal cover in burned plots was similar to nonburned plots. Crested wheatgrass basal cover was greater in plots receiving $46 \mathrm{~kg} \mathrm{~N} \cdot \mathrm{ha}^{-1}$ and $80 \mathrm{~kg} \mathrm{~N} \cdot \mathrm{ha}^{-1}(3.6 \%$ and $3.2 \pm 0.4 \% ; P<0.01$ ) than plots receiving $0 \mathrm{~kg} \mathrm{~N} \cdot \mathrm{ha}^{-1}$ $(1.7 \pm 0.4 \%)$.

Litter cover was greater following a wet spring than a dry spring $(35.6 \%$ vs. $7.8 \pm 1.3 \% ; P<0.01)$. Fire and nitrogen interacted in their effects on litter, with litter increasing with nitrogen amendment in nonburned plots $(P<0.01$; Fig. 5). However, nitrogen did not affect litter cover for summerburned plots and had little effect in fall-burned plots.

\section{Relative Composition}

Summer fire reduced purple threeawn composition by $63 \%$ following a wet spring and 50\% following a dry spring (Table 2). Fall-burned plots were similar to nonburned plots during a 
Table 1. Ground cover response to spring growing conditions, fire, and nitrogen amendments by effect and component.

\begin{tabular}{|c|c|c|c|}
\hline \multirow[b]{2}{*}{ Independent variable } & \multicolumn{2}{|c|}{ Basal cover (\%) } & \multirow[b]{2}{*}{ Bare ground $(\%)$} \\
\hline & Purple threeawn & Needle-and-thread & \\
\hline \multicolumn{4}{|l|}{ Year } \\
\hline Wet spring & $11.3 b^{1}$ & $0.7 \mathrm{~b}$ & $46.6 \mathrm{~b}$ \\
\hline Dry spring & $15.2 \mathrm{a}$ & $1.8 \mathrm{a}$ & $66.4 \mathrm{a}$ \\
\hline \multicolumn{4}{|l|}{ Fire } \\
\hline No burn & $32.5 \mathrm{a}$ & $2.1 \mathrm{a}$ & $32.4 \mathrm{c}$ \\
\hline Fall burn & $5.3 \mathrm{~b}$ & $0.7 \mathrm{~b}$ & $65.6 \mathrm{~b}$ \\
\hline Summer burn & $2.0 \mathrm{~b}$ & $0.9 \mathrm{~b}$ & $71.6 \mathrm{a}$ \\
\hline \multicolumn{4}{|l|}{ Nitrogen } \\
\hline $0 \mathrm{~kg} \mathrm{~N} \cdot \mathrm{ha}^{-1}$ & $13.8 \mathrm{a}$ & $1.1 \mathrm{a}$ & $60.3 \mathrm{a}$ \\
\hline $46 \mathrm{~kg} \mathrm{~N} \cdot \mathrm{ha}^{-1}$ & $13.6 \mathrm{a}$ & $1.1 \mathrm{a}$ & $53.8 \mathrm{~b}$ \\
\hline $80 \mathrm{~kg} \mathrm{~N} \cdot \mathrm{ha}^{-1}$ & $12.4 \mathrm{a}$ & $1.6 \mathrm{a}$ & $55.4 \mathrm{ab}$ \\
\hline
\end{tabular}

${ }^{1}$ Means with the same letters within year, fire, and nitrogen effect and response variable are similar $(P>0.05)$.

wet year, but purple threeawn composed a smaller percentage of relative composition during a dry year. Purple threeawn composition was similar in plots receiving $46 \mathrm{~kg} \mathrm{~N} \cdot \mathrm{ha}^{-1}$ and $80 \mathrm{~kg} \mathrm{~N} \cdot \mathrm{ha}^{-1}(40.9 \%$ and $37.3 \pm 2.1 \%)$ and less than plots receiving no nitrogen $(50.7 \pm 2.1 \% ; P<0.01)$. Summer fire doubled crested wheatgrass composition following a wet spring and more than tripled it following a dry spring (Table 2). Following a wet spring, crested wheatgrass composition on fallburned plots was similar to that of nonburned plots. Following a dry spring, crested wheatgrass composition more than doubled in fall-burned plots. Effects of nitrogen amendments of $46 \mathrm{~kg} \mathrm{~N} \cdot \mathrm{ha}^{-1}$ and $80 \mathrm{~kg} \mathrm{~N} \cdot \mathrm{ha}^{-1}$ on crested wheatgrass were similar to each other $(42.4 \%$ and $43.0 \pm 2.1 \%)$ and greater than $0 \mathrm{~kg} \mathrm{~N} \cdot \mathrm{ha}^{-1}(30.6 \pm 2.1 \% ; P<0.01)$.

Spring weather and nitrogen interacted in their effects on needle-and-thread composition $(P<0.03)$. Following a wet spring, needle-and-thread composition was similar across nitrogen treatments $(8.8 \pm 2.8 \%)$. Following a dry spring, needle-and-thread composition more than doubled with $80 \mathrm{~kg}$ $\mathrm{N} \cdot \mathrm{ha}^{-1}(16.4 \pm 2.8 \%)$ whereas plots receiving $0 \mathrm{~kg} \mathrm{~N} \cdot \mathrm{ha}^{-1}$ $(6.9 \pm 2.8 \%)$ and $46 \mathrm{~kg} \mathrm{~N} \cdot \mathrm{ha}^{-1}$ had intermediate levels

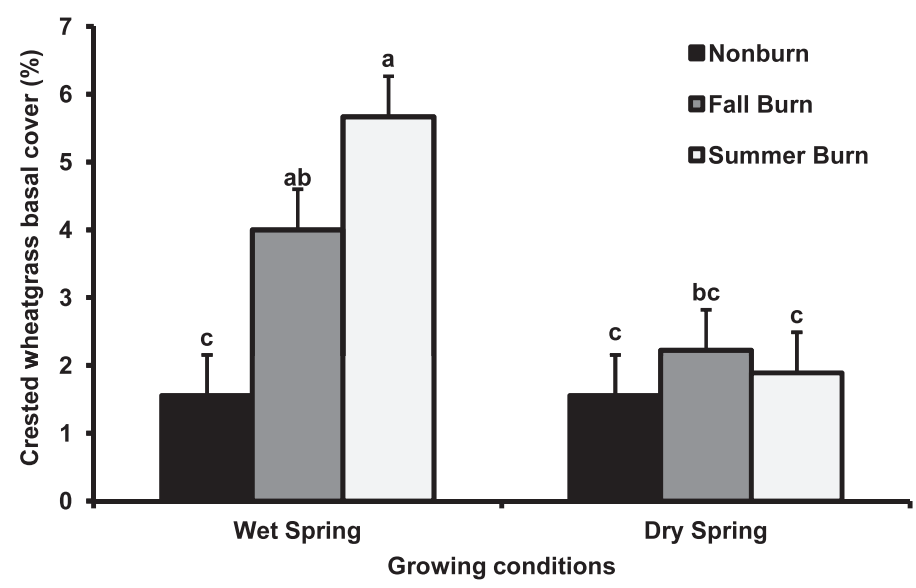

Figure 4. Fire effects on crested wheatgrass basal cover $(+S E c)$ one growing season postfire under wet and dry spring growing conditions. Means marked with the same letter are similar $(P>0.05)$.

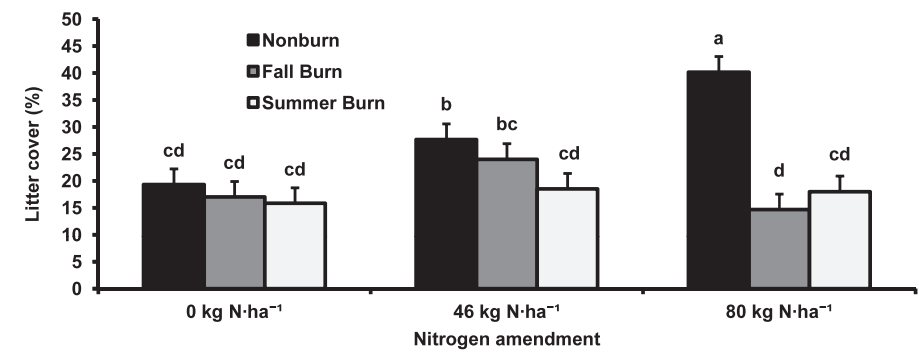

Figure 5. Fire $\times$ nitrogen effect on litter cover $(+\mathrm{SEc})$. Means marked with the same letter are similar $(P>0.05)$.

$(8.3 \pm 2.8 \%)$. Needle-and-thread composition in burned plots was similar to nonburned plots (Table 2). Composition of other perennial grasses was similar across nitrogen treatments and greater in summer*burned plots receiving $0 \mathrm{~kg} \mathrm{~N} \cdot \mathrm{ha}^{-1}$ than any other treatment (Table 2).

Spring weather and fire interacted in their effects on forb and annual grass composition (Table 2). Following a wet spring, summer and fall fire similarly reduced forb composition compared to nonburned plots. Following a dry spring, forb composition was similar in summer-burned, fall-burned, and nonburned plots. Forb composition was similar in plots receiving $0 \mathrm{~kg} \mathrm{~N} \cdot \mathrm{ha}^{-1}, 46 \mathrm{~kg} \mathrm{~N} \cdot \mathrm{ha}^{-1}$, and $80 \mathrm{~kg} \mathrm{~N} \cdot \mathrm{ha}^{-1}$ $(4.6 \pm 0.7 \% ; P>0.29)$. Summer and fall fire reduced annual grass composition compared to nonburned plots, following a wet spring (Table 2). Following a dry spring, annual grasses were almost nonexistent in burned and nonburned plots. Annual grass composition was similar in plots receiving $0 \mathrm{~kg}$ $\mathrm{N} \cdot \mathrm{ha}^{-1}, 46 \mathrm{~kg} \mathrm{~N} \cdot \mathrm{ha}^{-1}$, and $80 \mathrm{~kg} \mathrm{~N} \cdot \mathrm{ha}^{-1}(1.0 \pm 0.4 \%$; $P>0.29)$.

\section{DISCUSSION}

\section{Purple Threeawn Response}

Prescribed fire reduced purple threeawn abundance one growing season after fire. Observed decreases in current-year biomass of purple threeawn are similar to observations from southern mixed prairie and a greenhouse study (Steuter and Wright 1983; Russell et al. 2013). In addition to reductions in current-year biomass, our results indicated fire reduced purple threeawn basal cover, similar to experiments in shortgrass prairie and desert grassland (Trlica and Schuster 1969; Parmenter 2008; Killgore et al. 2009). Purple threeawn's sensitivity to fire stems from its hemicryptophyte (bunchgrass) growth form (Raunkiaer 1934) and its elevation of meristems into the crown of the plant as the growing season progresses (Ewing and Engle 1988). Bunchgrasses are generally more susceptible to fire damage than rhizomatous grasses are, because litter accumulates in the crown of bunchgrasses over time, increasing the fuel load associated with individual plants. Heavier fuel loads result in greater heating duration and heat dosage associated with individual plants, increasing the probability of fire damage occurring (Wright 1971; Engle et al. 1998; Vermeire and Rinella 2009; Vermeire and Roth 2011).

Summer fire produced greater or similar reductions in purple threeawn abundance compared to fall fire. Purple threeawn is a $\mathrm{C}_{4}$ grass and was active when we applied summer fires, but 
Table 2. Percent composition of canopy hits for three species and three species groups in response to fire and fire interactions with spring weather or nitrogen amendment.

\begin{tabular}{|c|c|c|c|c|c|}
\hline Response variable & No burn (\%) & Fall burn $(\%)$ & Summer burn (\%) & SEc & $P$ value \\
\hline \multicolumn{6}{|l|}{ Purple threeawn } \\
\hline Wet spring & $41.6 c^{1}$ & $37.2 \mathrm{c}$ & $15.1 d$ & 4.1 & 0.0144 \\
\hline Dry spring & $74.7 \mathrm{a}$ & $52.4 \mathrm{~b}$ & $36.9 \mathrm{c}$ & & \\
\hline \multicolumn{6}{|l|}{ Crested wheatgrass } \\
\hline Wet spring & $34.2 \mathrm{bc}$ & $41.6 \mathrm{bc}$ & $68.0 \mathrm{a}$ & 4.1 & 0.0099 \\
\hline Dry spring & $12.4 \mathrm{~d}$ & $33.7 \mathrm{c}$ & $42.1 \mathrm{~b}$ & & \\
\hline \multicolumn{6}{|l|}{ Forbs } \\
\hline Wet spring & $8.8 \mathrm{a}$ & $5.9 \mathrm{~b}$ & $3.6 \mathrm{bc}$ & 1.4 & 0.0095 \\
\hline Dry spring & $2.7 \mathrm{c}$ & $3.0 \mathrm{c}$ & $3.7 \mathrm{bc}$ & & \\
\hline \multicolumn{6}{|l|}{ Annual grass } \\
\hline Wet spring & $4.3 \mathrm{a}$ & $0.2 \mathrm{~b}$ & $1.3 \mathrm{~b}$ & 0.8 & 0.0031 \\
\hline Dry spring & $0.1 \mathrm{~b}$ & $0.0 \mathrm{~b}$ & $0.0 \mathrm{~b}$ & & \\
\hline Needle-and-thread & 7.8 & 10.3 & 11.1 & 2.8 & 0.4919 \\
\hline \multicolumn{6}{|c|}{ Other perennial grass } \\
\hline $0 \mathrm{~kg} \mathrm{~N} \cdot \mathrm{ha}^{-1}$ & $1.3 \mathrm{~b}$ & $3.8 a b$ & $6.5 \mathrm{a}$ & 1.6 & 0.0271 \\
\hline $46 \mathrm{~kg} \mathrm{~N} \cdot \mathrm{ha}^{-1}$ & $3.8 \mathrm{ab}$ & $2.5 \mathrm{~b}$ & $1.7 \mathrm{~b}$ & & \\
\hline $80 \mathrm{~kg} \mathrm{~N} \cdot \mathrm{ha}^{-1}$ & $3.5 a b$ & $2.3 \mathrm{~b}$ & $2.3 \mathrm{~b}$ & & \\
\hline
\end{tabular}

${ }^{1}$ Means with the same letters within species or species group are similar $(P>0.05)$.

dormant when we applied fall fires. Summer fire may be more desirable in ecosystems where plant communities evolved with recurrent summer fire (e.g., northern Great Plains) because species in these systems tend to be fire resilient (Wright and Bailey 1982) and will respond positively or remain stable with growing-season fire (Bates et al. 2009; Vermeire et al. 2011). Our results are strengthened by a consistent response one year postfire during years with very different postfire growing conditions.

Nitrogen had no direct effect on purple threeawn abundance. Our results are contrary to an initial report from eastern Colorado where purple threeawn yield and cover decreased with nitrogen additions (Hyder and Bement 1972), but similar to a second report from the same area where cover remained stable and yield increased or remained stable with nitrogen additions (Horn and Redente 1998). The negative impact of nitrogen on purple threeawn from the initial report appears to be a product of fortuitous events (Hyder et al. 1975). Research plots were treated with nitrogen in the fall and received aboveaverage temperatures and rainfall the following spring. The nitrogen amendments in conjunction with the above-average temperatures are believed to have caused purple threeawn to mobilize carbohydrates and begin growth. When spring temperatures returned to normal, mortality occurred in purple threeawn (Hyder et al. 1975). Our results and the results of others suggest purple threeawn does not consistently respond negatively to nitrogen amendments, but can be harmed when nitrogen amendments are combined with unique weather conditions.

Purple threeawn-dominated plant communities have been described as being stable (Costello 1944; Tomanek 1955; Paschke et al. 2000) but the mechanism supporting the stability of a purple threeawn-dominated plant community is unclear. Fire has been used in other plant communities to shift community composition and increase productivity (Steuter 1987; Howe 1995). Our results indicate fire disrupted the short-term stability of this community through reductions of purple threeawn basal cover and production $1 \mathrm{yr}$ following fire, subsequent increases in crested wheatgrass basal cover, and no change in $\mathrm{C}_{3}$ perennial grass production. However, with the short duration of our study we cannot say whether or not fire disrupted the long-term stability of this community. Additional research should focus on longer-term demography within purple threeawn-dominated plant communities.

\section{Other Species' Response}

Nitrogen amendments increased crested wheatgrass abundance and had the greatest effect when applied during a wet spring. The sensitivity of crested wheatgrass to nitrogen additions is documented in other studies (Black 1968; McGinnies 1968; Power and Alessi 1970) and was expected. Previous literature on rangeland fertilization in the northern Great Plains examined plant community response to nitrogen amendments and showed current-year production could be increased six times normal production with sustained effects for $2 \mathrm{yr}$ to $3 \mathrm{yr}$ (Rogler and Lorenz 1957; Cosper et al. 1967; Power 1974). However, those experiments used nitrogen amendments as high as $1000 \mathrm{~kg} \mathrm{~N} \cdot \mathrm{ha}^{-1}$ applied in successive years. Our study illustrates the influence of spring precipitation on nitrogen utilization and the yearly variation of weather conditions in the northern Great Plains. Furthermore, nutrient additions to rangelands are not recommended because they are rarely cost-effective (Rauzi 1978), decrease community diversity (DiTommaso and Aarssen 1989), increase the probability of invasion by weed species, and alter nutrient cycling over time (Wedin 1996).

Fire had no effect on $\mathrm{C}_{3}$ perennial grass biomass, a positive effect on crested wheatgrass basal cover, and a negative effect on needle-and-thread basal cover. Our results align with previous studies in northern mixed prairie that reported fire effects on $\mathrm{C}_{3}$ perennial grass production (Steuter 1987; Engle 
and Bultsma 1984; Vermeire et al. 2011). One discrepancy between our study and previous work is that we conducted our study on old agricultural fields seeded to crested wheatgrass, whereas previous results were from experiments on native rangeland. Crested wheatgrass' positive response to fire has been documented in other studies (Lodge 1960; Ralph and Busby 1979) and is indicative of the common fire history between the Eurasian steppe and North American grasslands.

Purple threeawn, crested wheatgrass, and needle-and-thread comprised $91.4 \%$ of the relative composition at the research sites. Forbs, annual grasses, and other perennial grasses were the groups comprising the remaining relative composition. In general, forb and annual grass relative composition were reduced with fire and were not affected by nitrogen amendments during a wet spring. Other perennial grasses increased in plots receiving summer fire and $0 \mathrm{~kg} \mathrm{~N} \cdot \mathrm{ha}^{-1}$ and were similar in all other fire and nitrogen combinations. The relative lack of species diversity in this plant community is characteristic of abandoned fields seeded to crested wheatgrass (Lesica and DeLuca 1996). Therefore, it is not surprising that the other species present were relatively unresponsive to our treatments. However, the substantial reductions of purple threeawn in the plant community suggest opportunities for establishment and/ or expansion exist for species present in sufficient numbers.

\section{MANAGEMENT IMPLICATIONS}

Earlier research suggested purple threeawn could be reduced with nitrogen amendments, and results were interpreted as nitrogen having a direct effect on purple threeawn. However, our results indicate nitrogen amendments had no impact on purple threeawn abundance under wet or dry growing conditions. Additionally, the tendency of nutrient additions to negatively impact overall ecosystem structure and function may counterbalance positive effects on individual species. Prescribed fire appears to be a highly effective rangeland management tool for reducing purple threeawn abundance. Our results show crested wheatgrass increased with reduced purple threeawn abundance. A reduction in purple threeawn and increase in crested wheatgrass would be desirable from a livestock management standpoint, increasing overall palatability of the plant community. Furthermore, fire removes litter accumulation in the crown of purple threeawn plants, mitigating one of purple threeawn's herbivory avoidance mechanisms and increasing the amount of forage available. The impact of summer fire on purple threeawn abundance indicates summer prescribed fire may be the most appropriate management tool for rehabilitating purple threeawn-dominated plant communities.

\section{ACKNOWLEDGMENTS}

The authors thank Nick Dufek, Morgan Russell, Marnie Rout, Bernadette Garber, and Kylie Jeffers for assistance in the field and laboratory. The Bureau of Land Management (BLM) provided major funding and logistical support. The Miles City BLM fire crews conducted prescribed fires. Jesse Hankins was liaison for the BLM. We appreciate the Larry Jens and Steve Tibbetts families for their cooperation.

\section{LITERATURE CITED}

Anderson, V. J., And D. D. Briske. 1995. Herbivore-induced species replacement in grasslands: is it driven by herbivory tolerance or avoidance? Ecological Applications 5:1014-1024.

Bates, J. D., E. C. Rhodes, K. W. Davies, and R. Sharp. 2009. Postfire succession in big sagebrush steppe with livestock grazing. Range Ecology \& Management 62:98110.

BLACK, A. L. 1968. Nitrogen and phosphorus fertilization for production of crested wheatgrass and native grass in northeastern Montana. Agronomy Journal 60:213-216.

Burke, I. C., W. K. Lauenroth, M. A. Vinton, P. B. Hook, R. H. Kelly, H. E. Epstein, M. R. Aguiar, M. D. Robles, M. O. Agullera, K. L. Murphy, and R. A. Gill. 1998. Plant-soil interactions in temperate grasslands. Biogeochemistry 42:121-143.

Cosper, H. R., J. R. Thomas, and A. Y. Alasyegh. 1967. Fertilization and its effect on range improvement in the northern Great Plains. Journal of Range Management 20:216-222

Costello, D. F. 1944. Natural revegetation of abandoned plowed land in the mixed prairie association of northeastern Colorado. Ecology 25:312-326.

DiTommaso, A., AND L. W. Aarssen. 1989. Resource manipulations in natural vegetation: a review. Plant Ecology 84:9-29.

Engle, D. M., And P. M. Bultsma. 1984. Burning of northern mixed prairie during drought. Journal of Range Management 37:398-401.

Engle, D. M., R. L. MitchelL, and R. L. Stevens. 1998. Late growing-season fire effects in mid-successional tallgrass prairies. Journal of Range Management 51:115121.

Evans, G. R., and E. W. TISDAle. 1972. Ecological characteristics of Aristida longiseta and Agropyron spicatum in west-central Idaho. Ecology 53:137-142.

Ewing, A. L., AND D. M. Engle. 1988. Effects of late summer fire on tallgrass prairie microclimate and community composition. American Midland Naturalist 120:212-223.

FowleR, N. L. 1984. Patchiness in patterns of growth and survival of two grasses. Oecologia 62:424-428.

FowLER, N. L. 1986. Microsite requirements for germination and establishment of three grass species. American Midland Naturalist 115:131-145.

Heitschmidt, R. K., D. D. Briske, and D. L. Price. 1990. Pattern of interspecific tiller defoliation in mixed-grass prairie grazed by cattle. Grass and Forage Science 45:215-222.

Horn, B. E., and E. F. Redente. 1998. Soil nitrogen and plant cover of an old-field on the shortgrass steppe in southeastern Colorado. Arid Soil Research and Rehabilitation 12:193-206.

Howe, H. F. 1995. Succession and fire season in experimental prairie plantings. Ecology 76:1917-1925.

Hyder, D. N., And R. E. Bement. 1972. Controlling red three-awn on abandoned cropland with ammonium nitrate. Journal of Range Management 25:443-446.

Hyder, D. N., R. E. Bement, E. E. Remmenga, and D. F. Hervey. 1975. Ecological responses of native plants and guidelines for management of shortgrass range. Washington, DC, USA: USDA-ARS. Technical Bulletin 1503. 87 p.

JudD, B. I. 1974. Plant succession of old fields in the Dust Bowl. The Southwestern Naturalist 19:227-239.

KEPE, T. 2005. Grasslands ablaze: vegetation burning by rural people in Pondoland, South Africa. South African Geographical Journal 87:10-17.

Killgore, A., E. Jackson, and W. G. Whitford. 2009. Fire in Chihuahuan Desert grassland: short-term effects on vegetation, small mammal populations, and faunal pedoturbation. Journal of Arid Environments 73:1029-1034.

LESICA, P., AND T. H. DELUCA. 1996. Long-term harmful effects of crested wheatgrass on Great Plains grassland ecosystems. Journal of Soil and Water Conservation 51:408-409.

Littell, R. C., G. A. Milliken, W. W. Stroup, R. D. Wolfinger, and 0. Schabenberger. 2006. SAS for mixed models. 2nd ed. Cary, NC, USA: SAS Institute Inc. $780 \mathrm{p}$.

LODGE, R. W. 1960. Effects of burning, cultivation, and mowing on the yield and consumption of crested wheatgrass. Journal of Range Management 13:318321.

McGinNies, W. J. 1968. Effect of nitrogen fertilizer on an old stand of crested wheatgrass. Agronomy Journal 60:560-562. 
McWillams, J. L., and P. E. Van Cleave. 1960. A comparison of crested wheatgrass and native grass mixtures seeded on rangeland in eastern Montana. Journal of Range Management 13:91-94.

MeYER, M. W., AND R. D. Brown. 1985. Seasonal trends in the chemical composition of ten range plants in south Texas. Journal of Range Management 38:154-157.

Milchunas, D. G., W. K. Lauenroth, P. L. Chapman, and M. K. Kazempour. 1989. Effects of grazing, topography, and precipitation on the structure of a semiarid grassland. Vegetatio 80:11-23.

Parmenter, R. R. 2008. Long-term effects of a summer fire on desert grassland plant demographics in New Mexico. Rangeland Ecology \& Management 61:156-168.

PascheE, M.W., T. McLendon, and E.F. Redente. 2000. Nitrogen availability and old-field succession in a shortgrass steppe. Ecosystems 3:144-158.

Paton, C. J., and K. G. Rickert. 1989. Burning, then resting, reduces wiregrass (Aristida spp.) in black speargrass pastures. Tropical Grasslands 23:211-218.

Power, J. F. 1974. Urea as a nitrogen fertilizer for Great Plains grasslands. Journal of Range Management 27:161-164.

Power, J. F. AND J. AlessI. 1970. Effects of nitrogen source and phosphorus on crested wheatgrass growth and water use. Journal of Range Management 23:175-178.

Ralph, M. H., AND F. E. Busby. 1979. Prescribed burning: vegetative change, forage production, costs and returns on six demonstration burns in Utah. Journal of Range Management 32:267-270.

RAUNKIAER, C. 1934. The life forms of plants and statistical plant geography. London, UK: Clarendon. $632 \mathrm{p}$

Rauzl, F. 1978. High rates of nitrogen change composition of shortgrass rangeland in southeastern Wyoming. Journal of Range Management 31:366-370.

Rogler, G. A., AND R. J. LoRenz. 1957. Nitrogen fertilization of northern Great Plains rangelands. Journal of Range Management 10:156-160.

Russell, M. L., L. T. Vermeire, N. A. Dufek, and D. J. Strong. 2013. Fire, defoliation, and competing species alter Aristida purpurea biomass, tiller, and axillary bud production. Rangeland Ecology \& Management 66:290-296.

Smeins, F. E., T. W. Taylor, and L. B. Merrill. 1976. Vegetation of a 25 year exclosure on the Edwards Plateau, Texas. Journal of Range Management 29:24-29.
Steuter, A. A. 1987. $C_{3} / C_{4}$ production shift on seasonal burns: northern mixed prairie. Journal of Range Management 40:27-31.

Steuter, A. A., And H. A. WriGht. 1983. Spring burning effects on redberry junipermixed grass habitats. Journal of Range Management 36:161-164.

Tomanek, G. W., F. W. Albertson, and A. Riegel. 1955. Natural revegetation on a field abandoned for thirty-three years in central Kansas. Ecology 36:407-412.

TrLicA, M. J., AND J. L. Schuster. 1969. Effects of fire on grasses of the Texas high plains. Journal of Range Management 22:329-333.

USDA-NRCS. 2010a. Official soil series description. Available at: https://soilseries.sc. egov.usda.gov/osdname_look.aspx. Accessed 30 November 2010.

USDA-NRCS. 2010b. The PLANTS database. Available at: http://plants.usda.gov. Accessed 24 September 2010.

Vermeire, L. T., J. L., Crowder and D. B. Wester. 2011. Plant community and soil environment response to summer fire in the northern Great Plains. Rangeland Ecology \& Management 64:37-46.

Vermeire, L. T., and M. J. Rinella. 2009. Fire alters emergence of invasive plant species from soil surface-deposited seeds. Weed Science 57:304-310.

Vermeire, L. T., AND A. D. Roth. 2011. Plains prickly pear response to fire: effects of fuel load, heat, fire weather, and donor site soil. Rangeland Ecology \& Management 64:404-413.

WEDIN, D. A. 1996. Nutrient cycling in grasslands: an ecologist's perspective. In: R. E. Joost and C. A. Roberts [EDS.]. Nutrient cycling in forage systems. Manhattan, KS, USA: Potash and Phosphate Institute. p. 29-44.

Western Regional Climate Center. 2012. Western U.S. climate historical summaries. Available at http://www.wrcc.dri.edu/cgi-bin/cliMAIN.pl?mt8165. Accessed 4 September 2012.

White, R. S., AND P. O. CuRRIE. 1983. Prescribed burning in the northern Great Plains: yield and cover responses of 3 forage species in the mixed grass prairie. Journal of Range Management 36:179-183.

WRIGHT, H. A. 1971. Why squirreltail is more tolerant to burning than needle and thread. Journal of Range Management 24:277-284.

Wright, H. A., AND A. W. Balley [EDS.]. 1982. Fire ecology: United States and southern Canada. New York, NY, USA: John Wiley \& Sons. $501 \mathrm{p}$. 